\title{
TIPOLOGI KODIFIKASI KITAB HADIS AL-MA’'̄̄IM
}

\author{
Muhammad Kudhori \\ Ssekolah Tinggi Agama Islam Al-Fithrah Surabaya \\ khudhori8 $\overline{4}$ gmail.com
}

Diterima 28 Maret 2018 | Direview 23 Agustus 2018|Diterbitkan 01 Oktober 2018

\begin{abstract}
The method which is used by theologian in hadith codification has a trend that change from time to time. After third century of hijriyah, some theologians arrange hadith's book using the method that has already taught to them before, but others have a different method. One of the method which is dissimilar from others is hadith codification method or it is called $M u$ 'jam. Mu'jam is a hadith codification typology that is based on the friend of the Prophet's musnad or the writer's teacher that is arranged based on alphabet. In some sample, it is seemed that Mu'jam's book also shows some friends of the Prophet's biography before showing the history of them. Mu'jam's book is classified into two groups. They are Mu'jam al-Shuyūkh (based on teacher's names) and Mu'jam al-Sahāabah (based on friends of the Prophet's names). Commonly, there are some quality of hadith s in Mu'jam's books. There are sahịh, hasan, da îf even mawḍu' (false). One of the benefit in Ma 'ajim's book is as the main reference of Prophet's musnad hadith. It means continued until the Prophet himself and containing lots of hadith that is not found in al-Kutüb al-Sittah. Moreover, Mu'jam's book is one of the main references to know the biography of Sahabat (friend's Prophet), nasab (offspring), and their virtue.
\end{abstract}

Keywords: Method, mu'jam, hadith, codification.

\begin{abstract}
Abstrak
Metode yang dipakai oleh para ulama dalam kodifikasi hadis mengalami semacam trend yang berubah dari masa ke masa. Setelah abad ketiga hijriyah, para ulama dalam menyusun kitab hadis ada yang mengikuti metode ulama sebelumnya, ada juga yang berbeda. Salah satu metode yang berbeda itu adalah metode kodifikasi hadis dalam bentuk Mu'jam. Mu'jam adalah tipologi kodifikasi hadis yang didasarkan pada musnad sahabat maupun nama para guru penulis yang disusun berdasarkan huruf abjad. Dalam beberapa sampel terlihat bahwa kitab Mu'jam terkadang juga menampilkan biografi para sahabat terlebih dahulu sebelum menampilkan riwayat dari para sahabat tersebut. Kitab Mu'jam dapat dikelompokkan menjadi dua, Mu'jam al-Shuyūkh (berdasarkan nama-nama para guru) dan Mu'jam alSahābah (berdasarkan nama-nama para sahabat). Secara umum dalam kitab-kitab Mu'jam terdapat berbagai kualitas hadis, mulai dari șaḥiḥ, hasan, ḍa îf bahkan mawḍ̄' (palsu). Manfaat kitab Ma 'äjim di antaranya adalah sebagai referensi induk hadis-hadis Nabi Saw. yang musnad (bersambung dan sampai pada Nabi Saw.) dan memuat banyak hadis yang tidak terdapat dalam al-Kutūb al-Sittah. Selain itu kitab Mu'jam juga merupakan salah satu referensi utama dalam mengetahui biografi para sahabat, nasab dan keutamaan mereka.
\end{abstract}

Kata kunci: Metode, mu'jam, hadis, kodifikasi.

\section{Pendahuluan}

Tidak dapat disangkal lagi bahwa kegiatan tulis menulis dan kegiatan pendidikan di dunia Islam telah berlangsung sejak zaman Nabi Saw. Ini dapat dilihat dengan adanya bukti-bukti bahwa ketika Nabi Saw. masih hidup, para sahabat banyak yang mencatat hal-hal yang diimlā'kan Nabi Saw. kepada mereka. Ada juga sejumlah sahabat yang menyimpan surat-surat Nabi atau salinannya. Sahabat Hudhayfah ra. menuturkan bahwa Nabi meminta dituliskan nama orang-orang yang masuk Islam, maka Hudhayfah menuliskannya sebanyak 1500 orang. Selain itu ada juga aturan registrasi nama orangorang yang mengikuti perang. Rasulullah Saw. pada saat itu juga telah mempunyai juru tulis wahyu yang jumlahnya mencapai empat puluh orang. Beliau juga mempunyai sekretaris yang bertugas untuk mencatat sadaqah dan $m u^{\prime}$ 'amalah. Selain itu beliau juga 
telah mempunyai sekretaris yang bertugas menulis surat untuk para raja-raja di sekitar Arab dengan bahasa yang berbeda-beda.

Sesuatu yang tidak diragukan lagi bahwa hadis Nabi Saw. belum terkodifikasi pada masa Nabi Saw. dan para sahabat, meskipun sebagian sahabat telah menulis hadishadis Nabi Saw. Upaya itu tidak bisa dikatakan sebagai upaya kodifikasi, karena upaya tersebut merupakan upaya yang bersifat individual dan untuk koleksi pribadi. Tidak dibukukannya hadis pada masa itu tidak lepas dari dua hal. Pertama; adanya sebagian hadis yang melarang untuk menulis hadis, juga karena ada kekhawatiran bahwa hadishadis yang ditulis akan tercampur dengan al-Qur'ān. Kedua; karena kehebatan para sahabat pada waktu itu dalam hafalan, sehingga mereka tidak butuh terhadap tulisan. Juga karena kebanyakan di antara mereka tidak mengetahui tulis menulis. ${ }^{2}$

'Abd al-'Azīs bin Marwān yang menjadi penguasa Mesir pada saat itu (65-85 H.) telah berusaha melakukan kodifikasi hadis-hadis Nabi Saw. Ia menulis surat kepada Kathïr bin Murrah al-Hadrami -yang menjumpai tujuh puluh sahabat yang ikut perang badar- untuk menulis hadis-hadis yang ia dengar dari para sahabat selain Abü Hurayrah, karena hadis-hadis riwayat Abü Hurayrah telah terkumpul dan berada di tangan 'Abd al-'Azīs bin Marwān. Namun para ahli tidak mengetahui hasil dari usaha yang dilakukan oleh 'Abd al-'Azīs bin Marwān ini. ${ }^{3}$

Kemudian pada saat 'Umar bin 'Abd al-'Azis menjadi khalifah, ia menulis surat kepada Abū Bakr bin Hazm, gubernurnya yang berada di Madinah untuk menulis hadishadis Nabi Saw. 'Umar bin 'Abd al-'Azis juga menulis surat kepada para ulama yang berada di daerah-daerah Islam lain untuk menulis dan mengumpulkan hadis-hadis Nabi Saw. Akan tetapi 'Umar bin 'Abd al-'Azīs meninggal terlebih dahulu sebelum Abū Bakr bin Hazm mengirim hasil usahanya mengumpulkan hadis-hadis Nabi kepadanya. Sehingga, usaha kodifikasi ini belum bisa dikatakan sempurna dan maksimal. ${ }^{4}$

Usaha kodifikasi secara sempurna dilakukan oleh Mụ̣ammad bin Shihāb al-Zuhrī (w. 124 H.) ketika ia memenuhi permintaan Khalifah 'Umar bin 'Abd al-'Azis untuk mengumpulkan hadis-hadis Nabi Saw. Hadis-hadis itu kemudian diserahkan kepada Khalifah 'Umar bin 'Abd al-'Azis dan kemudian di kirim ke daerah-daerah Islam. Kodifikasi ini merupakan kodifikasi pertama kali yang dilakukan secara sempurna dan teliti. Usaha kodifikasi ini kemudian diikuti oleh para ulama pada masa-masa berikutnya. Tidak kurang dari dua puluh ulama yang mengikuti jejak al-Zuhri ini, di antaranya yang terkenal dan kitab-kitabnya dapat kita jumpai saat ini adalah: Mālik bin Anas (w. 179 H.) dengan kitabnya al-Muwattă', 'Abd al-Razzāq bin Himām al-Șhan'anī (w. 211 H.) dengan kitabnya Musannaf 'Abd al-Razzāq dan Ibn Abi Shaybah (w. 235 H.) dengan kitabnya Mushannaf Ibni Abï Shaybah. ${ }^{5}$

Jika diamati, metode yang dipakai oleh para ulama dalam kodifikasi hadis mengalami semacam trend yang berubah dari masa ke masa, mulai dari al-Muwattāa, alMușannaf, al-Musnad, al-Jämi“ dan al-Sunan. Setelah abad ketiga hijriyah, dalam menyusun kitab hadis para ulama ada yang mengikuti metode ulama sebelumnya, ada juga yang berbeda dengan metode yang telah ditempuh oleh ulama sebelumnya. Salah satu metode yang berbeda itu adalah metode kodifikasi hadis dalam bentuk Mu'jam.

\footnotetext{
${ }^{1}$ Muhammad 'Ajāj al-Khatịib, al-Sunnah Qabl al-Tadwin, (Beirut: Dar al-Fikr, 1993), h. 298.

${ }^{2}$ Ibn Hajar al-'Asqalāni, Muqaddimah Fath al-Bāri (Beirut: Dār al-Ma'rifah, 1379 H.), h. 4.

${ }^{3}$ Akram Dịā' al-'Umarì, Buhūth fì Tärikh al-Sunnah al-Musharrafah (Madinah: Maktabah al'Ulūm wa al-Hikam, t.th.), h. 298.

${ }^{4}$ Ibid., h. 298-299.

${ }^{5}$ Ibid., h. 299-301.
} 
Artikel akan mengulas tentang metode $M u^{\prime}$ jam. Bagaimana pengertian dan karakteristik kitab $M u^{\prime} j a m$, sehingga dapat diperoleh definisi dan gambaran yang komprehensif tentang tipologi kitab hadis bergenre $M u^{\prime}$ jam.

\section{Definisi $\mathrm{Mu}^{\prime} \mathrm{jam}$}

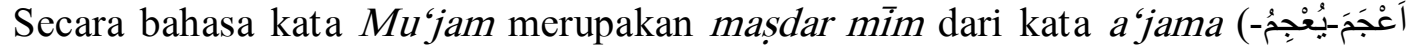

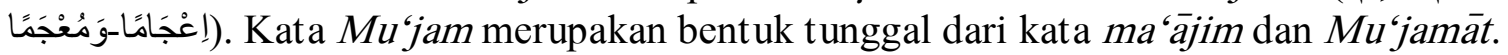
Orang Arab sering berujar:

$$
\text { أعجم الكلام او الكتاب اذا أزال عجمته و ابهامه بالنقط والنكل. }
$$

"Seseorang menjelaskan perkataan atau kitabnya (tulisannya) ketika ia menghilangkan kesamaran (ketidak jelasan) perkataan atau kitab (tulisan) tersebut dengan memberi titik dan harakat."

Dalam istilah ahli bahasa kata $M u^{\prime}$ jam mempunyai arti susunan materi sebuah buku yang berdasarkan huruf hija' ${ }^{-}{ }^{\prime} y h^{7}{ }^{7}$ Adapun dalam istilah ahli hadis, kata $M u^{6}$ jam didefinisikan sebagai berikut:

a. 'Ubaidullāh bin Muhammad 'Abd al-Salām al-Mubārakfūrì dalam kitabnya Mir' ${ }^{\prime} \bar{t}$ al-Mafätịh Sharh Mishkāt al-Mașābịh dan Sayyid Ṣadiq Hasan al-Qanūji dalam kitabnya al-Hittah fi Dhikr al-Sihàh al-Sittah mendefinisikan Mu 'jam sebagai:

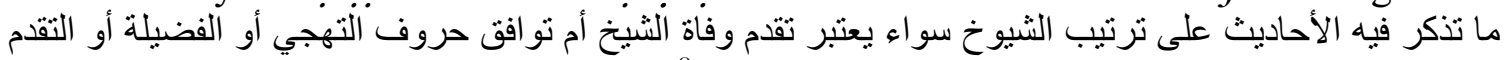

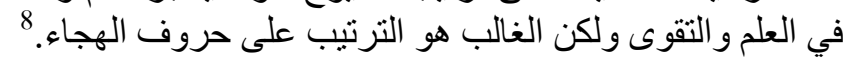

"Mu'jam adalah kitab yang di dalamnya berisi hadis-hadis sesuai dengan susunan para guru, baik berdasarkan urutan wafat, kesamaan huruf hija'iyah, keutamaan, keunggulan dalam ilmu maupun ketakwan guru tersebut. Namun pada umumnya kitab tersebut disusun berdasarkan urutan huruf hijà'iyyah."

b. Muḥammad bin Ja'far al-Kattānì dalam kitabnya al-Risālah al-Mustatrafah mendefinisikan $M u^{\prime}$ jam sebagai: مروف الذكر فيه الأحاديث على ترتيب الصحابة أو الثيوخ أو البلدان أو غير ذلك و الغالب ان يكونوا مرتبين على

" $M u$ 'jam adalah kitab yang di dalamnya berisi hadis-hadis sesuai dengan urutan para sahabat, guru, daerah atau yang lainnya dimana pada umumnya susunan sahabat, guru atau daerah tersebut berdasarkan urutan huruf abjad."

c. Maḥmūd al-Ṭaḥhān dalam kitabnya Usūul al-Takhrīj wa Dirāsat al-Asānīd mendefinisikan $M u^{\prime}$ jam sebagai:

الأستاب الذي ثُرتب فيه الأحاديث على مسانيد الصحابة، أو الثيوخ، أو البلدان، أو غير ذلك. و الغالب أن يكون ترتيب

"Mu'jam adalah kitab yang didalamnya disusun hadis-hadis berdasarkan musnad sahabat, para guru, daerah atau yang lainnya. Pada umumnya susunan nama-nama tersebut berdasarkan huruf $M u$ 'jam (abjad)."

\footnotetext{
6'Ubaidullāh bin Muhammad 'Abd al-Salām al-Mubārakfūrī, Mir'āt al-Mafātịh Sharh Mishkāt alMașābịh, vol. 1 (Banaras: Idārah al-Buhūth al-'Ilmiyyah wa al-Da'wah wa al-Iftā', 1984), 407. Sayyid 'Abd al-Mājid al-Ghawrī, Mawsū'ah 'Ulūm al-Hadith wa Funūnih, vol. 3 (Damaskus: Dār Ibn Kathïr, 2007), h. 349-350.

${ }^{7}$ Sayyid 'Abd al-Mājid al-Ghawrī, Mawsū'ah 'Ulūm al-Hadith wa Funūnih, h. 350.

${ }^{8}$ Al-Sayyid Șadiq Ḥasan al-Qanūji, al-Hitttah fĭ Dhikr al-Sịhạh al-Sittah (Beirut: Dār al-Kutub alTa‘Timiyyah, 1985), h. 53.

${ }^{9}$ Muḥammad bin Ja'far al-Kattānī, al-Risālah al-Mustatrafah li Bayān Mashhür Kutub al-Sunnah al-Mușannafah (Beirut: Dār Bashā'ir al-Islāmiyyah, 1986), h. 90.

${ }^{10}$ Badrān al-'Ayyārī, Sharh Kitāo Ușūl al-Takhrīj wa Dirāsat al-Asānīd(t.t.: t.p, t.th.), h. 13.
} 
d. 'Abdullāh al-Sa'd dalam kitabnya Sharh al-Mūqiḍah fí 'Ilm al-Muștalah menjelaskan:

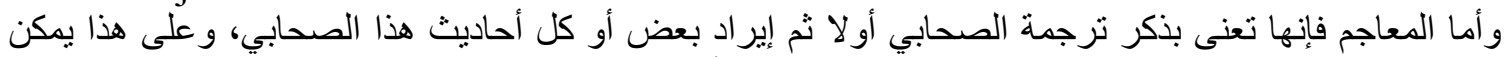

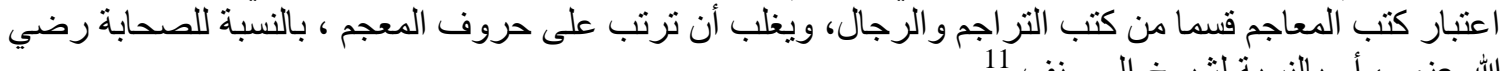

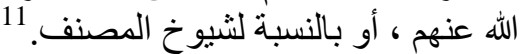
"Adapun yang dimaksud dengan al-Ma 'ājim, maka yang dikehendaki adalah kitab yang menyebutkan biografi para sahabat pada permulaannya, kemudian menampilkan sebagian atau keseluruhan hadis-hadis yang diriwayatkan oleh sahabat tersebut. Dari definisi ini, bisa dikatakan bahwa kitab al-Ma'ājim merupakan bagian dari kitab-kitab al-Tarājum wa al-Rijāl (biografi para tokoh). Biasanya penyusunan kitab $M u$ 'jam diurutkan sesuai dengan urutan abjad, baik dinisbatkan kepada para sahabat tersebut maupun kepada para guru penulisnya."

e. Muhammad Khalaf Salāmah dalam kitabnya Lisān al-Muhaddithīn menjelaskan lebih rinci, bahwa $M u$ 'jam dalam tipologi kodifikasi hadis mempunyai dua pengertian. Pertama adalah al-Musnad yang di dalamnya menyebutkan para sahabat sesuai dengan urutan huruf abjad, seperti $M u$ 'jam al-Sahābah yang disusun oleh al-Baghāwì dan Ibn Qāni'. Juga Mu'jam al-Kabīr yang disusun oleh al-Ṭabrānī. Kedua adalah kitab yang menyebutkan nama para guru penyusunnya beserta sebagian riwayat mereka, terkadang juga menyebutkan biografi mereka. Ketika sistem penyusunan kitab ini berdasarkan urutan abjad, maka kitab ini disebut dengan Mu'jam al-Shuyūkh. ${ }^{12}$

Dari definisi-definisi yang telah disebutkan di atas, dapat dilihat bahwa korelasi antara definisi $M u$ 'jam secara bahasa dan secara istilah adalah ketika seorang penulis $M u^{\prime}$ jam berpedoman pada susunan urut an nama-nama guru mereka sesuai dengan huruf abjad, setidaknya mereka telah menghilangkan kesamaran nama-nama guru mereka dan memudahkan dalam meneliti guru-guru mereka yang terdapat dalam kitab mereka. ${ }^{13}$

\section{Macam-Macam Kitab Mu'jam dan Karakteristiknya}

Kitab Mu'jam yang ditulis oleh para ulama jumlahnya sangan banyak. Oleh karena itu, dalam tulisan ini tidak akan diurai seluruh kitab $M u^{\prime}$ jam yang ada. Penulis hanya akan mengulas secara ringkas beberapa kitab $M u^{\prime} j a m$ yang dianggap paling penting dan ditulis lebih awal. Harapannya, dengan menampilkan beberapa sampel kitab $M u$ 'jam ini, dapat diketahui secara komprehensif gambaran umum tentang kitab $M u^{\prime}$ jam beserta karakteristiknya.

a. Mu'jam Abī Ya'lā al-Mawșili (210-307 H.)

Kitab Mu'jam ini ditulis oleh Abū Ya'lā al-Mawșili Ahmad bin 'Ali bin alMuthannā al-Tamīmi (210-307 H.), Săhịib al-Musnad. Al-Mawșili telah melakukan rihlah sejak masa kecil dan bertemu dengan tokoh-tokoh hadis pada masa itu. Ia berguru pada Ahmad bin Mani'‘, Khalifah bin Khayyāt, Abū Khaythamah Zuhayr bin Harb dan tokoh-tokoh besar lainnya. Ia menyebutkan guru-gurunya itu dalam kitab $M u^{\prime}$ jamnya. Tentang al-Mawșili, al-Dāruquṭni berkata, "thiqat ma'mūn". Tokoh besar hadis yang

${ }^{11}$ Abdullāh al-Sa‘d, Sharh al-Müqị̣ah fí 'Ilm al-Muștalah, vol. 1 (t.t.: t.p., t.th.), h. 143.

${ }^{12}$ Muhammad Khalaf Salāmah, Lisān al-Muhaddithïn, vol. 5 (t.t.: t.p., t.th.), h. 133

${ }^{13}$ Sayyid 'Abd al-Mājid al-Ghawrī, Mawsù'ah 'Ulūm al-Hadith wa Funūnih, h. 350. Lihat juga dalam Muqaddimah al-Mu'jam fí Asāmīi Suyūkh Abī Bakr al-'Ismāiili, vol. 1 (Madinah: Maktabah al'Ulūm wa al-Hikam, 1990), h. 223. 
meriwaykan darinya antara lain adalah al-Nasā'ī, Ibn Hibbān dan al-Ṭabrānì. Abū Hạatim al-Bustī berkata: "Antara ia dan Rasulullah Saw. ada tiga orang." "14

Sayyid 'Abd al-Mājid al-Ghawrì menyebutkan bahwa dalam $M u$ 'jamnya Abū Ya'lā al-Mawșili meriwayatkan dari 335 shaikh. Dari setiap shaikh terdapat beberapa hadis, minimal satu. Ia menyusun nama-nama shaikhnya itu sesuai huruf abjad dan mendahulukan shaikhnya yang bernama Muhammad dalam rangka mencari berkah. ${ }^{15}$

Dalam kitab Mu'jam Abi Ya'lā yang ditahqīq oleh Irshād al-Haqq al-Athari pada bab orang-orang yang namanya Muhammad setidaknya ada 67 hadis yang dirawayatkan dari guru yang bernama Muhammad. Namun setelah diteliti, ternyata pada hadis ke 43 dan 47, nama guru yang disebutkan bukanlah nama Muḥammad, melainkan Abū Bakr bin Abī Naḍr dan Abū 'Ubaidah bin Fudail bin 'Iyād, sebagaimana data berikut:

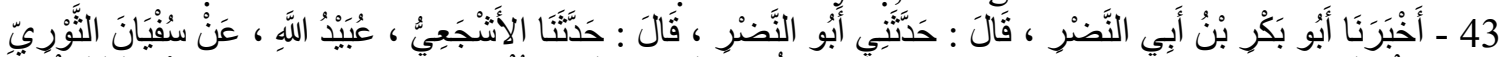

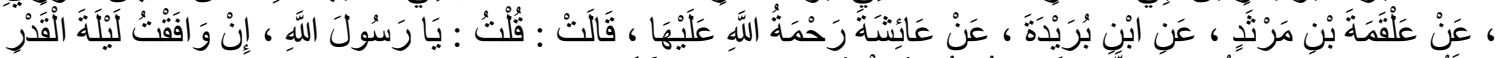

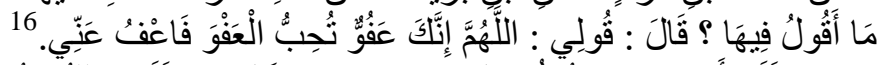

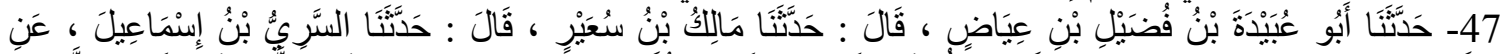

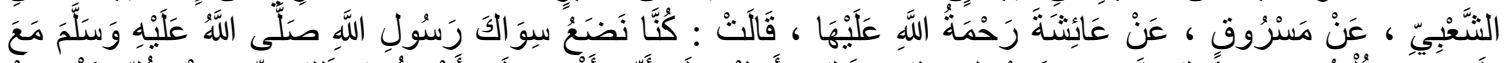

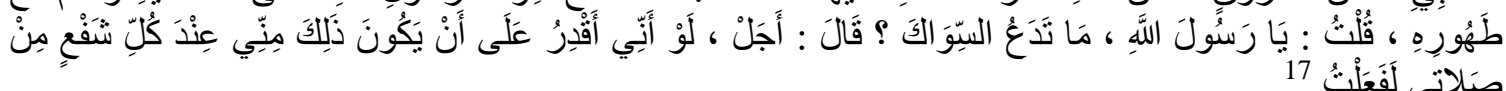

Setelah selesai menyebutkan guru-guru yang bernama Muhammad, maka yang ditulis berikutnya adalah guru-guru yang nama depannya diawali dengan huruf alif. Pada bab huruf alif ini yang pertama kali dicantumkan adalah guru-gurunya yang bernama Aḥmad, lalu berturut-turut yang bernama Ibrāhīm, Isḥāq, Ismā'î̀, kemudian guru-guru yang namanya diawali dengan huruf alif secara acak, tanpa memperhatikan urutan huruf abjad. Ini dapat dilihat ketika nama Ayyūb dicantumkan lebih dulu dari pada al-Azraq. ${ }^{18}$ Begitu seterusnya pada bab huruf $b a$ ' dan yang lainnya.

Kitab Mu'jam Abī Ya'lā al-Mawșili ini diterbitkan pada tahun $1410 \mathrm{H}$. oleh penerbit Dār al-'Ulūm al-Athariyyah di Fayṣal Ābād, Pakistan dengan pentahqīi Irshād al-Haqq al-Atharì dan juga diterbitkan oleh penerbit Dār al-Ma'mūn di Damaskus pada tahun 1410 H. dengan pentahqiq Husayn Asad al-Dārānī dan 'Abduh Kushk. ${ }^{19}$

b. $\quad$ Mu'jam al-Sahăbah al-Baghawīi (214-317 H.)

Kitab Mu'jam ini ditulis oleh 'Abdullāh bin Muhammad bin 'Abd al-'Azīz Abū Qāsim al-Baghawì. Ia lahir pada hari Senin awal Ramaḍ̄n $214 \mathrm{H}^{20}$ dan wafat pada malam 'Td al-Fițrí $317 \mathrm{H}^{21}$ Guru-gurunya di antaranya adalah Aḥmad bin Ḥanbal, 'Ali bin al-Madini, 'Ali bin al-Ja'd dan lain sebagainya. Sementara murid-muridnya di antaranya adalah Yahyā bin Șāiid, Ibn Qāni‘, Abū Ḥātim Ibn Ḥibbān dan Abū Bakr alIsmā $\bar{i} T_{i}{ }^{22}$

Dalam kitab $M u$ 'jamnya ini al-Baghawī menyusunnya sesuai dengan nama-nama para sahabat berdasarkan huruf abjad. Pertama-tama ia menyebutkan biografi sahabat

\footnotetext{
${ }^{14}$ Lihat biografinya lebih detail dalam Muhammad bin Aḥmad al-Dhahabī, Siyar A 'lām al-Nubalā', vol. 27 (Beirut: Mu'assasah al-Risālah, t.th.), h. 190-197.

${ }^{15}$ Sayyid 'Abd al-Mājid al-Ghawrī, Mawsū'ah 'Ulüm al-Hadith wa Funūnih, h. 353.

${ }^{16} \mathrm{Abì} \mathrm{Ya}$ 'lā al-Mawșili, al-Mu'jam (Faiṣal Ābād: Idārah al-'Ulū al-Athariyyah, 1407 H.), h. 66.

${ }^{17}$ Ibid., h. 69

${ }^{18}$ Ibid., h. 114-115.

${ }^{19}$ Sayyid 'Abd al-Mājid al-Ghawrī, Mawsū'ah 'Ulūm al-Hadith wa Funūnih, h. 353.

${ }^{20}$ Muḥammad bin Aḥmad al-Dhahabī, Siyar A'lām al-Nubalā', vol. 28 (Beirut: Mu'assasah alRisālah, t.th.), h. 3.

${ }^{21}$ Ibid., h. 19.

${ }^{22}$ Ibid., h. 4-5.
} 
tersebut, terkadang secara ringkas, terkadang juga secara detail. Kemudian ia menyebutkan riwayat-riwayat yang menjelaskan keutamaan para sahabat tersebut, terkadang tanpa sanad dan terkadang pula menggunakan sanad. Selanjutnya ia menuliskan hadis-hadis yang diriwayatkan oleh sahabat tersebut. ${ }^{23}$ Berikut contohnya:

$$
\text { 1- أبو المنذر ويقال أبو الطفيل أبي بن كمن اسمب أبي: سكن المدينة ومات بها. }
$$

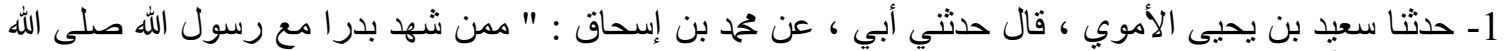

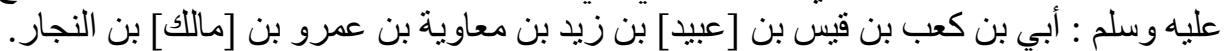

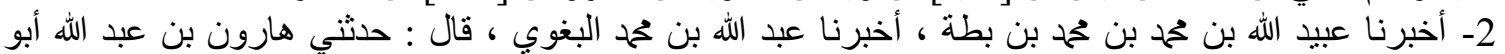

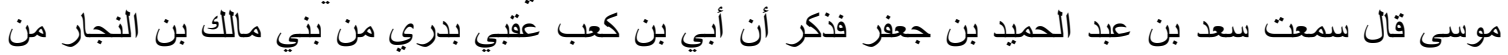

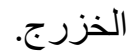

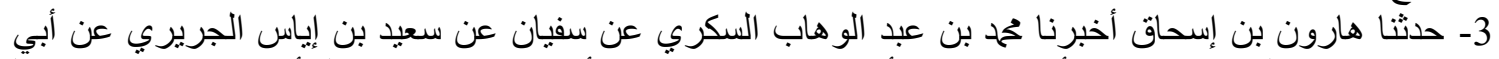

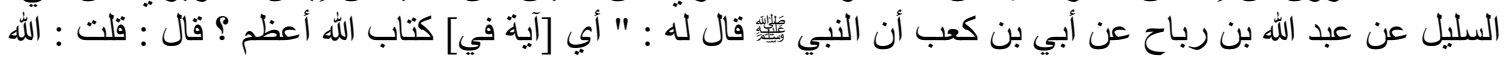

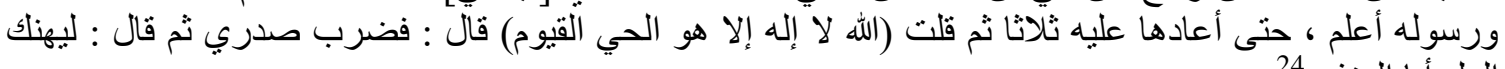

c. Mu'jam Ibn al-A'rābīi (w. 340 H.)

Mu'jam ini ditulis oleh Ahmad bin Muhammad bin Ziyād bin Bishr, alImām al-Muhaddith al-Qudwah al-Ṣadūq al-Ḥāiz, Shaikh al-Islām Abū Sađid bin al-A'rabì al-Bașrí al-Șüfi, tinggal di Makkah dan seorang shaikh di tanah haram. Ia lahir setelah tahun $240 \mathrm{H}$. Gurunya di antaranya adalah al-Ḥasan bin Muḥammad bin al-Șabbāh al-Za'farānī, 'Abdullāh bin Ayyūb al-Mukharrimī dan yang lainnya. Ia melakukan rihlah ke beberapa daerah, seorang ahli ibadah dan menulis Manāqib al-Süfiyyah. Murid-muridnya di antaranya adalah Abū 'Abdillāh bin Khafíf dan Abū Bakr bin al-Muqrì'. ${ }^{25}$ Ia juga berteman dengan al-Junaid. ${ }^{26}$ Ibn al-A'rabi merupakan ulama sufi, namun ia tidak menerima sesuatu pun dari istilah-istilah para sufi kecuali dengan hujjah. ${ }^{27}$ Ia meninggal pada bulan Dhulqa'dah $340 \mathrm{H}$. Usianya 94 tahun. ${ }^{28}$ Namun menurut catatan $\mathrm{Abū} \mathrm{Nu}$ 'aym, ia meninggal pada tahun $341 \mathrm{H}^{29}$

Dalam kitab $M u$ 'jamnya ini Ibn al-A'rabì meriwayatkan dari 336 shaikh. Setiap shaikh disebutkan beberapa hadis hingga kadang-kadang mencapai 90 hadis. Ibn al-A'rabī menyusun nama-nama gurunya berdasarkan huruf abjad dengan mempertimbangkan huruf awalnya saja, sebagaimana dalam $M u$ 'jam $A b \bar{i}$ $Y a$ Ta. Ia juga mendahulukan nama-nama gurunya yang bernama Muhammad dalam rangka mencari berkah. ${ }^{30}$ Setelah nama Muhammad selesai disusul dengan jajaran guru-gurunya yang bernama Aḥmad. Kitab $M u$ 'jam Ibn al-A'rābi ini memuat 2395 hadis. ${ }^{31}$

\footnotetext{
${ }^{23}$ Muhammad al-Amīn bin Muḥammad al-Jankī, Muqaddimah Mưjam al-Sahābah (Kuwait: Dār al-Bayān, 2000), h. 43.

${ }^{24} \mathrm{Abū}$ al-Qāsim al-Baghawī, Mu 'jam al-Ṣahābah, vol. 1(Kuwait: Dār al-Bayān, 2000), h. 3-6.

${ }^{25}$ Lihat biografinya lebih detail dalam Muhammad bin Ahmad al-Dhahabī, Siyar A 'lām al-Nubalā', vol. 29 (Beirut: Mu'assasah al-Risālah, t.th.), h. 401-404. Abū Nu'aym Aḥmad bin 'Abdillāh al-Aṣbahānī, Hilyat al-Awliyā' wa Tabaqāt al-Așfiyā', vol. 10 (Beirut: Dār al-Kitāb al-‘Arabī, 1405 H.), h. 375.

${ }^{26}$ Sayyid 'Abd al-Mājid al-Ghawrì, Mawsū'ah 'Ulüm al-Hadith wa Funünih, h. 354.

${ }^{27}$ Muḥammad bin Aḥmad al-Dhahabì, Siyar A 'lām al-Nubalā', h. 404.

${ }^{28}$ Ibid.

${ }^{29} \mathrm{Abū} \mathrm{Nu}$ 'aym Ahmad bin 'Abdillāh al-Aṣbahānī, Hilyat al-Awliyā', h. 375.

${ }^{30}$ Sayyid 'Abd al-Mājid al-Ghawrī, Mawsū'ah 'Ulüm al-Hadith wa Funūnih, h. 354.

${ }^{31}$ Lihat Ahmad bin Muhammad bin Ziyād bin Bishr al-Baṣri, Mu'jam Ibn al-A 'rābìi (t.t.: t.p., t.th.)
} 
Kitab Mu'jam Ibn al-A'rābì pertama kali diterbitkan dalam dua juz oleh penerbit Maktabah al-Kawthar Riyāḍ pada tahun 1412 H. dengan ditahqiq oleh alShahỉd Ahmad Mir al-Bullūshi. ${ }^{32}$

d. Ma'ājim al-Tabrānì (260-360 H.)

Nama al-Ṭabrānì adalah Abū al-Qāsim Sulaymān bin Aḥmad bin Ayyūb bin Muțīi al-Lukhamī al-Shāmī al-Ṭabrānì. Ia dilahirkan di kota 'Akkā, pada bulan Șafar $260 \mathrm{H}^{33}$

Guru-gurunya di antaranya adalah Hāshim bin Marthad, Aḥmad bin Mas'ūd al-Khayyāt, 'Amr bin Abī Salamah al-Tinnisisi, Ahmad bin 'Abdullāh alLihyā̄ī, 'Amr bin Thawr, Ibrāhīm bin Abī Sufyān, Abū Zur'ah al-Dimashqīi, Ishạāq bin Ibrāhīm al-Dabrì, Idrīs bin Ja'far al-'Atțār, Abū Dawūd al-Ṭayālisī, Abū 'Abdirrahmān al-Nasā̄'i dan lain sebagainya. Di kota Ṭabariyyah al-Ṭabrāni berguru kepada lebih dari seribu orang guru. Ia melakukan rihlah dan berguru kepada para ulama di Makkah, Madinah, Yaman, kota-kota yang ada di Shām, Mesir, Baghdād, Küfah, Baṣrah, Aṣbahān dan lain sebagainya. Ia kemudian tinggal di Aṣbahān kurang lebih selama enam puluh tahun, menulis dan menyebarkan ilmunya. ${ }^{34}$ Sementara murid-muridnya di antaranya adalah Abū Khalifah al-Jumahị, al-Hāfiz Ibn 'Uqdah, mereka berdua sekaligus juga menjadi guru al-Ṭabrāni, Ahmad bin Muḥammad bin Ibrāhīm al-Ṣaḥhạf, Ibn Mundah, Abū Bakr bin Mardawayh dan lain sebagainya. ${ }^{35}$

Al-Ṭabrāni menulis tiga kitab Mu'jam yang sangat terkenal, yaitu alMu'jam al-Kabir, al-Mu'jam al-Awsat dan al-Mu'jam al-Saghïr. Abū Nu'aym alHậfiz mengatakan bahwa al-Ṭabrāni wafat pada bulan Dhulqa'dah $360 \mathrm{H}$. di Aṣbahān. Dengan demikian usianya mencapai seratus tahun sepuluh bulan. ${ }^{36}$ Menurut satu pendapat, kedua matanya mengalami kebutaan di akhir hidupnya. Al-Ṭabrāni berkata: "Al-Zanādiqah telah menyihirku." "37

a. Al-Mu'jam al-Kabïr

Al-Kattāni yang juga dikutip oleh Sayyid 'Abd al-Mājid al-Ghawri menjelaskan bahwa kitab al-Mu'jam al-Kabir disusun berdasarkan nama-nama sahabat sesuai dengan huruf abjad, kecuali musnad Abi Hurayrah, karena alṬabrani menyendirikannya dalam sebuah karya tersendiri. Dikatakan bahwa dalam al-Mu'jam al-Kabïr, al-Ṭabrāni menyebutkan enam puluh ribu hadis dalam dua belas jilid kitab. Ibn Dihyah mengatakan bahwa al-Mu'jam al-Kabïr merupakan kitab $M u$ 'jam yang paling besar di dunia ini. Ketika disebut kata al$M u$ 'jam secara mutlak, maka yang dimaksud adalah al-Mu'jam al-Kabïr karya al-Ṭabrani. Sedangkan apabila yang dikehendaki yang lainnya, maka penyebutannya diikuti dengan kata yang lain. ${ }^{38}$

Ketika kita meneliti kitab al-Mu'jam al-Kabïr karya al-Ṭabrani, maka kita akan mendapati bahwa pokok pembicaraan dari kitab tersebut adalah

\footnotetext{
${ }^{32}$ Sayyid 'Abd al-Mājid al-Ghawrì, Mawsū'ah 'Ulūm al-Hadith wa Funūnih, h. 354.

${ }^{33}$ Muḥammad bin Aḥmad al-Dhahabi, Siyar A'lām al-Nubalā', vol. 31 (Beirut: Mu'assasah alRisālah, t.th.), h. 135.

${ }^{34}$ Ibid., h. 135-137.

${ }^{35}$ Ibid., h. 138.

${ }^{36}$ Ibid., h. 148 .

${ }^{37}$ Ibid., h. 146.

${ }^{38}$ Muhammad bin Ja'far al-Kattānī, al-Risālah al-Mustatrafah li Bayān Mashhūr Kutub al-Sunnah al-Musannafah, h. 90.
} 
mengetahui para sahabat dengan menyebutkan ihwal dan keutamaan mereka, lalu menyebutkan riwayat-riwayat mereka, baik sebagian maupun keseluruhannya yang disusun berdasarkan urutan abjad. Ia pun memulai susunan para sahabat itu dengan diawali nama-nama sepuluh para sahabat yang dijamin masuk surga oleh Nabi Saw. Dalam muqaddimahnya al-Ṭabrānī berkata:

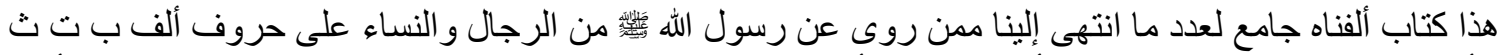
بدأت فيه بالعشرة رضي الله عنهم لأن لا يتقدمه أحد غير هم خرجت عن عن كل و واحد منهم حديثا وحديثين وثنالثا و أكثر

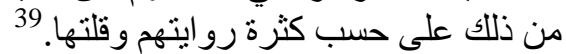

"Kitab ini aku susun dalam rangka mengumpulkan riwayat-riwayat yang telah sampai kepada kami dari orang-orang yang meriwayatkannya dari Rasulullah Saw., baik dari kalangan sahabat laki-laki maupun perempuan sesuai dengan huruf alif, ba, ta, tha. Aku memulainya dengan menyebutkan sepuluh sahabat yang dijamin surga, karena sesungguhnya tidak ada orang lain yang mendahului mereka. Aku mengeluarkan satu, dua, tiga hadis atau lebih dari tiap-tiap mereka sesuai banyak dan sedikitnya riwayat mereka."

Dari keterangan di atas, maka manhaj al-Ṭabrānī dalam al-Mu'jam al-Kabïr secara ringkas dapat disimpulkan sebagai berikut: ${ }^{40}$

1) Al-Ṭabrāni menampilkan riwayat-riwayat dari tiap-tiap sahabat baik yang mukthir (banyak riwayatnya) maupun yang mutawassit. Ia tidak menampilkan riwayat-riwayat Abū Hurayrah, karena ia menyusunnya tersendiri dalam sebuah musnad. Juga karena riwayat Abū Hurayrah yang sangat banyak. Menurut al-Dhahabì, al-Mu'jam al-Kabïr juga tidak menampilkan semua hadis riwayat para sahabat yang banyak meriwayatkan hadis (al-mukthirin). ${ }^{41}$

2) Al-Ṭabrāni menampilkan semua riwayat sahabat-sahabat yang sedikit periwayatan hadisnya (al-Muqillün). ${ }^{42}$

3) Al-Ṭabrāni mencantumkan nama-nama sahabat yang tidak mempunyai riwayat dan memperkenalkan sahabat itu dengan menyebutkan keutamaankeutamaannya dari riwayat-riwayat yang berasal dari selain mereka, karena sasaran penulisan kitab $M u$ 'jam ini adalah untuk mengetahui para sahabat. ${ }^{43}$

4) Al-Ṭabrānī menyusun nama-nama para sahabat itu berdasarkan huruf abjad. ${ }^{44}$ Namun ia mendahulukan nama-nama sepuluh sahabat yang dijamin masuk surga oleh Nabi Saw. yang dimulai dari Abū Bakr, 'Umar, 'Uthmān, 'Ali dan seterusnya dengan terlebih dahulu menampilkan riwayat-riwayat yang menjelaskan identitas mereka yang meliputi nama, keutamaan dan lain sebagainya. Kemudian disusul dengan sahabat-sahabat yang lain berdasarkan

\footnotetext{
${ }^{39}$ Sulaymān bin Ahmad bin Ayyūb bin Muṭī al-Lukhamī al-Shāmī al-Ṭabrānī, al-Mu jam al-Kabīr, vol. 1 (t.t.: t.p., t.th.), h. 1.

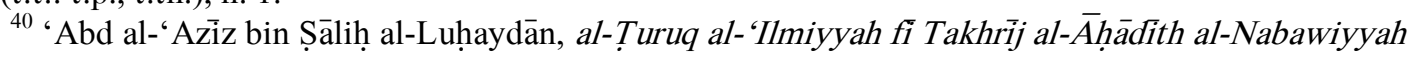
(t.t.: t.p., t.th.), h. 47.

${ }^{41}$ Muhammad bin Ahmad al-Dhahabī, Siyar A 'lām al-Nubalā', h. 139.

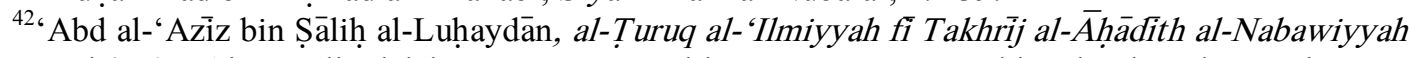
(t.t.: t.p., t.th.), 47. Al-Muqill adalah perawi yang sedikit periwayatannya dibandingkan dengan kawankawannya. Lihat Sayyid 'Abd al-Mājid al-Ghawrì, Mawsū'ah 'Ulūm al-Hadith wa Funūnih, 420. Menurut Sa'd bin 'Abdullāh Âlu Hamid, al-Muqillūn adalah para perawi yang hanya meriwayatkan satu atau dua hadis saja. (Fatāwä Hadithiyyah, 86.)

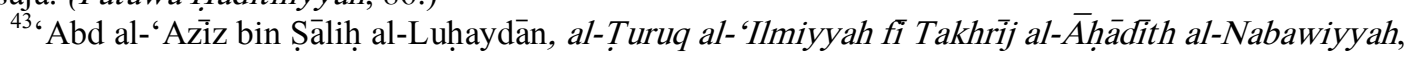
h. 47.$$
{ }^{44} \text { Ibid. }
$$ 
huruf abjad. Adapun untuk kalangan șahābiyyāt, ia memulainya dengan musnad-musnad putri-putri Nabi Saw. Ia memulai dari Fațimah, Zaynab, Ruqayyah dan Ummu Kulthūm. Kemudian Umāmah binti Abì al-'Aṣ yang merupakan putri Zaynab. Lalu berikutnya adalah istri-istri Nabi Saw. yang diawali dari Khadijah, ' $\bar{A}$ 'ishah kemudian istri-istri Nabi yang lain. Setelah itu dilanjutkan dengan nama-nama șậabiyyāt berdasarkan huruf abjad. ${ }^{45}$ Tentang hal ini al-Tabrāni mengatakan:

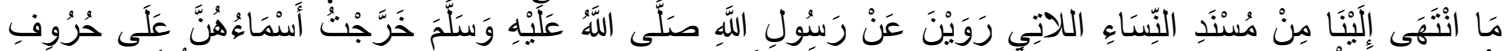

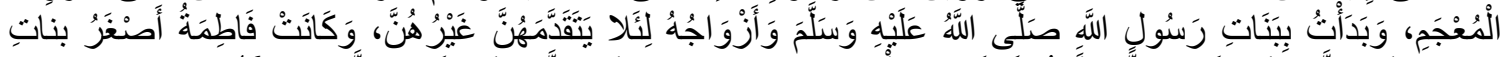

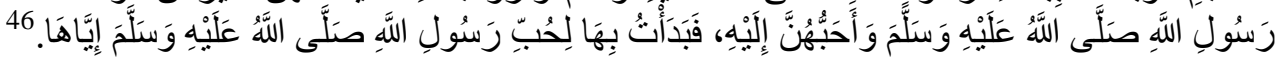

"Musnad para tokoh perempuan yang meriwayatkan dari Rasulullah Saw. yang telah sampai kepada kami, kami paparkan nama-nama mereka berdasarkan huruf abjad. Saya mulai dengan nama-nama putri Rasulullah Saw. kemudian istri-istrinya, supaya selain mereka tidak ada yang mendahului mereka. Fațimah adalah putri Rasulullah Saw. yang terkecil dan paling dicintai oleh Rasulullah Saw. Aku menuliskannya pertama kali karena kecintaan Rasulullah Saw. kepadanya."

Menurut penilitian 'Abd al-'Azīz bin Șāliḥ al-Luhaydān, jumlah sahabat yang hadisnya ditakhrijj oleh al-Ṭabrāni beserta dengan biografi mereka mencapai 1600 sahabat. Al-Ṭabrāni juga terkadang menjelaskan nama-nama sahabat yang diperselisihkan dan menjelaskan hal itu. Hal ini seperti yang dilakukannya ketika menampilkan nama Jundub bin Ka‘b al-Azdi:

$$
\begin{aligned}
& \text { جُنْنُبُ بن كَعْبِ الأَزْدِيُّ }
\end{aligned}
$$

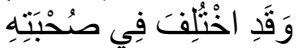

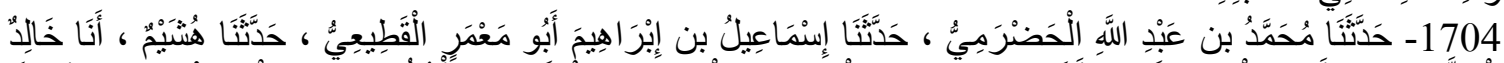

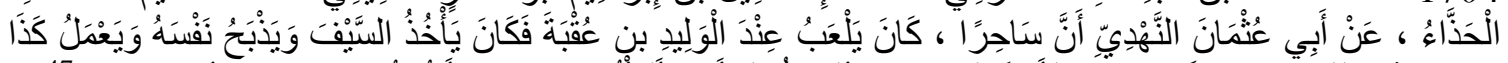

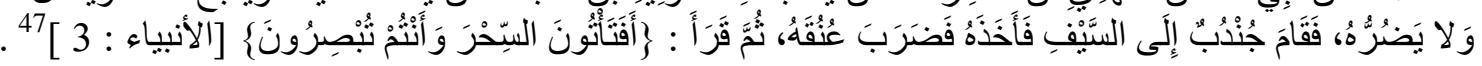

Hadis-hadis yang terdapat dalam al-Mu'jam al-Kabir mencakup hadis-hadis marfü ‘ (ini yang terbanyak), kemudian mawqüf, terlebih ketika al-Ṭabrāni memulai musnadnya dengan menampilkan biografi sahabat terlebih dahulu dan menyebutkan keutamaan-keutamaannya. Dalam al-Mu'jam al-Kabïrjuga terdapat ucapan para tābi în dan rawi-rawi di bawah mereka yang berkaitan dengan hal ihwal para sahabat. ${ }^{48}$

Dalam al-Mu'jam al-Kabïr juga terdapat pendapat-pendapat al-Ṭabrānì sendiri, baik yang berkaitan dengan ihwal para sahabat maupun dalam rangka menjelaskan katakata yang dianggap asing, seperti ketika al-Tabrāni menjelaskan kata al-Hashsh yang menurutnya artinya adalah al-Bustān (kebun). ${ }^{\dot{4} 9}$

\footnotetext{
${ }^{45}$ Ibid., h. 50.

${ }^{46}$ Sulaymān bin Aḥmad bin Ayyūb bin Muṭī al-Lukhamī al-Shāmī al-Ṭabrānī, al-Mu'jam al-Kabīr, vol. 16 (t.t.: t.p., t.th.), h. 250-251.

${ }^{47}$ Sulaymān bin Aḥmad bin Ayyūb bin Muṭī al-Lukhamī al-Shāmī al-Ṭabrānī, al-Mu'jam al-Kabīir, vol. 2 (t.t.: t.p., t.th.), h. 244.

${ }^{48} \mathrm{Ibid}$.

${ }^{49}$ Sulaymān bin Aḥmad bin Ayyūb bin Muṭīr al-Lukhamī al-Shāmī al-Ṭabrānī, al-Mu'jam al-Kabīr, vol. 1, h. 42 .
} 
Al-Mu'jam al-Kabir pertama kali diterbitkan oleh Kementrian Wakaf Irak pada tahun 1398 H. yang ditahqīq oleh Hamdí 'Abd al-Majīd al-Salafi. Kemudian diterbitkan untuk yang kedua kalinya oleh penerbit al-Zahrā' al-Hadithah. ${ }^{50}$

\section{b. $\quad$ Al-Mu'jam al-Awsät}

Al-Mu'jam al-Awsăt merupakan kitab $M u$ 'jam kedua yang ditulis oleh al-Ṭabrānī. Menurut al-Kattāni, al-Ṭabrāni menyusun kitab ini berdasarkan nama-nama gurunya. Jumlah mereka kurang lebih mencapai 2000 orang, hingga ia meriwayatkan dari orang yang lahir setelahnya, karena keluasan riwayat dan gurunya yang sangat banyak. Dalam al-Mu'jam al-Awsät al-Ṭabrānī memperbanyak hadis-hadis gharīb yang berasal dari guru-gurunya. ${ }^{51}$ Al-Dhahabi mengatakan :

$$
\text { فإنه تعب عهيه, وفيه كنل نفيس و وعزيز ومنكر. }
$$

"Al-Mu 'jam al-Awsāt sama dengan kitab al-Afrād yang ditulis oleh al-Dāruquṭni. Di dalamnya ia menjelaskan keutamaan dan keluasan riwayatnya. Al-Ṭabrāni berkata: "Kitab ini adalah ruhku.", karena ia bersusah payah dalam menyusunnya. Di dalamnya terdapat hadis-hadis yang bagus, 'azizz dan munkar."

Al-Ṭabrāni menyusun nama-nama gurunya ini berdasarkan huruf abjad yang

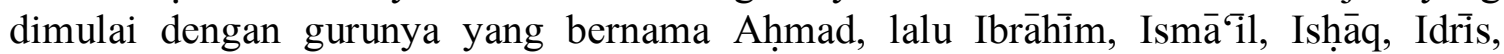
Ayyūb, Anas, Abān dan seterusnya tanpa memperhitungkan huruf keduanya. ${ }^{53}$ Bisa ditebak ketika al-Ṭabrāni dalam kitabnya ini mendahulukan nama Ahmad lalu namanama nabi yang lain, tidak lain karena bertujuan untuk mencari berkah (tabarruk), sebagaimana yang dilakukan oleh pendahulunya seperti Abū Ya'lā al-Mawșili dan Ibn al-A'rabī.

Jumlah hadis yang terdapat dalam al-Mu'jam al-Awsăt yang telah diterbitkan sebanyak 9485 hadis. Menurut Sayyid 'Abd al-Mājid al-Ghawri, jumlah ini masih kurang $^{54}$, karena ada yang mengatakan bahwa jumlah hadisnya mencapai $30000 .{ }^{55} \mathrm{Kitab}$ al-Mu'jam al-Awsät diterbitkan oleh Maktabah al-'Ārif Riyạd yang ditahqīq oleh Maḥmūd al-Ṭaḥhān pada tahun 1405-1415 H. Kemudian diterbitkan lagi oleh penerbit Dār al-Ḥaramayn di Kairo yang di taḥqīq oleh Ṭāriq 'Iwạ̣ dan 'Abd al-Muhsin Ibrāhìm al-Ḥusayni pada tahun $1415 \mathrm{H}^{56}$

c. Al-Mu'jam al-Saghir

Al-Mu'jam al-Saghir merupakan kitab Mu'jam ketiga yang ditulis oleh al-Ṭabrāni. Kitab al-Mu'jam al-Saghïr juga disusun berdasarkan nama-nama para guru al-Ṭabrāni. Di dalamnya pada umumnya al-Ṭabrani hanya membatasi satu hadis dari setiap gurunya. Hal ini berdasarkan pernyataanya dalam permulaan kitabnya:

\footnotetext{
${ }^{50}$ Sayyid 'Abd al-Mājid al-Ghawrī, Mawsū'ah 'Ulūm al-Hadith wa Funūnih, vol. 3 (Damaskus: Dār Ibn Kathir, 2007), h. 354.

${ }^{51}$ Muhammad bin Ja‘far al-Kattānī, al-Risālah al-Mustatrafah li Bayān Mashhūr Kutub al-Sunnah al-Muṣannafah (Beirut: Dār Bashā'ir al-Islāmiyyah, 1986), h. 90.

${ }^{52}$ Muhạmmad bin Aḥmad al-Dhahabì, Tadhkirat al-Huffä, vol. 3 (Beirut: Dār al-Kutub al'Ilmiyyah, 1998), h. 85.

${ }^{53}$ Sulaymān bin Aḥmad bin Ayyūb bin Muṭir al-Lukhamī al-Shāmī al-Ṭabrānī, al-Mu'jam al-Awsăt (Kairo: Dār al-Ḥaramayn, 1415 H.)

${ }^{54}$ Sayyid 'Abd al-Mājid al-Ghawri, Mawsū'ah 'Ulüm al-Hadith wa Funūnih, h. 355.

${ }^{55} \mathrm{Ab \overline {u }}$ Jamīl al-Ḥasan al-'Ilmī, Ummahāt Kutub al-Hadith wa Manāhij al-Taṣnīf 'Inda alMuḥaddithīn (t.t.: Ma'had al-Gharb al-Islāmī, 2005), h. 51.

${ }^{56}$ Ibid.
} 


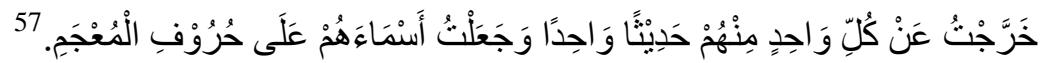

Ia mentakhrīj dari seribu shaykh. Menurut al-Kattāni yang juga dikutip oleh Abū Jamīl al-Hasan al-'Ilmī, jumlah hadisnya sebanyak 1500 hadis. ${ }^{58}$ Sedangkan menurut Sayyid 'Abd al-Mājid al-Ghawri, jumlah hadisnya hanya 1200 hadis. ${ }^{59}$ Nama-nama gurunya dalam kitab ini juga disusun berdasarkan huruf abjad yang dimulai dengan gurunya yang bernama Aḥmad, lalu Ibrāhīm, Ismā'îl, Ishāā, Ayyūb dan seterusnya tanpa memperhitungkan huruf keduanya. ${ }^{60}$

Kitab al-Mu'jam al-Saghir diterbitkan di Delhi India pada tahun 1311 H. Kemudian diterbitkan oleh Maktabah al-Salafiyah di Madinah yang di taṣhịh oleh 'Abd al-Raḥmān Muḥammad 'Uthmān pada tahun 1388 H. Juga diterbitkan oleh Dār Ihȳā' al-Turāth al-'Arabì di Beirut dengan ditaḥqīq oleh Muhammad Salim Samārah pada tahun $1411 \mathrm{H}^{61}$

e. Mu'jam Abï Bakr al-Ismāîili (277-371 H.)

Kitab Mu'jam ini ditulis oleh Shaykh al-Islām Abū Bakr Ahmad bin Ibrāhīm al-Ismā ‘َili al-Jurjāni. Seorang tokoh dan imam dalam madhhab al-Shāfi $\mathfrak{i}$ pada masanya. Ia lahir pada tahun $277 \mathrm{H}^{62}$ dan wafat pada tahun $371 \mathrm{H}^{63}$ Gurugurunya di antaranya adalah Abū Khalifah, al-Jamhịi, Ibn Khuzaymah, Abū Ya'lā, Ibn Abī Shaybah, al-Firyānī dan lain sebagainya. ${ }^{64^{\circ}}$ Sementara murid-muridnya di antaranya adalah al-Hākim, al-Barqānì, Hamzah al-Sahmī dan lain sebagainya. ${ }^{65}$

Mu'jam Abi Bakr al-Ismā'ili disusun berdasarkan nama-nama gurunya. Di dalamnya ia mentakhrij dari 410 guru. Dari setiap guru terdapat satu hadis yang dianggap asing atau dianggap baik, atau berupa hikayah yang disertai dengan kritiknya. Kitab ini diterbitkan oleh Maktabah al-'Ulūm wa al-Hikam di Madinah pada tahun $1410 \mathrm{H}$. dengan ditaḥqīq oleh Muhammad Ziyād Manșūr. ${ }^{66}$

f. Mu'jam Ibn Jumay'(305-402 H.)

Kitab Mu'jam ini ditulis oleh Abū al-Ḥasan Muhammad bin Ahmad bin

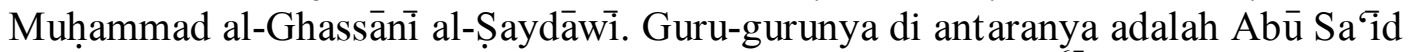
bin al-A'rabī, al-Mahāmi Ti, Ibn Makhlad dan lain sebagainya. ${ }^{67}$ Sementara muridmuridnya di antaranya adalah 'Abd al-Ghanì bin Sa 'id al-Hāfiz, Tammām al-Rāzì dan lain sebagainya. ${ }^{68}$ Ia lahir pada tahun $305 \mathrm{H}$. dan wafat pada tahun $402 \mathrm{H}^{69}$

\footnotetext{
${ }^{57}$ Sulaymān bin Aḥmad bin Ayyūb bin Muṭīr al-Lukhamī al-Shāmī al-Ṭabrānī, al-Mu'jam alSaghir, vol. 1 (Beirut: al-Maktab al-Islāmi, 1985), h. 21.

${ }^{58}$ Muhammad bin Ja'far al-Kattānì, al-Risālah al-Mustatrafah li Bayān Mashhūr Kutub al-Sunnah al-Musannafah, h. 90.

${ }^{59}$ Sayyid 'Abd al-Mājid al-Ghawrī, Mawsū'ah 'Ulūm al-Hadith wa Funūnih, h. 355.

${ }^{60}$ Sulaymān bin Aḥmad bin Ayyūb bin Muṭir al-Lukhamì al-Shāmī al-Ṭabrānī, al-Mu'jam al-Saghìr (Beirut: al-Maktab al-Islāmī, 1985)

${ }^{61}$ Sayyid 'Abd al-Mājid al-Ghawrī, Mawsū'ah 'Ulūm al-Hadith wa Funūnih, h. 355.

${ }^{62}$ Muhạmmad bin Ahmad al-Dhahabī, Tadhkirat al-Huffaz, vol. 3 (Beirut: Dār al-Kutub al'Ilmiyyah, 1998), h. 106.

${ }^{63}$ Ibid., h. 108.

${ }^{64}$ Ibid., h. 106. Abū Jamīl al-Ḥasan al-'Ilmì, Ummahāt Kutub al-Hadith wa Manāhij al-Taṣnîf 'Inda al-Muhaddithin, h. 53.

${ }^{65}$ Ibid.

${ }^{66}$ Sayyid 'Abd al-Mājid al-Ghawrì, Mawsū'ah 'Ulūm al-Hadith wa Funūnih, 355-356.

${ }^{67}$ Muhammad bin Aḥmad al-Dhahabi, Siyar A'lām al-Nubalā', vol. 33 (Beirut: Mu'assasah alRisālah, t.th.), h. 147.

${ }^{68}$ Ibid., h. 149.

${ }^{69}$ Ibid., h. 149-150.
} 
Dalam kitab ini Ibn Jumay' mentakhrijj dari 378 guru. Ia menyusun namanama gurunya berdasarkan huruf abjad dan dimulai dengan guru-gurunya yang bernama Muhammad dalam rangka tabarrukan. Dari setiap guru ia meriwayatkan satu hadis atau hikayah. Mu'jam Ibn Jumay'diterbitkan oleh penerbit Mu'assasah al-Risālah di Beirut pada tahun 1405 dengan ditahqīiq oleh 'Umar 'Abd al-Salām al-Tadmūri. $^{70}$

\section{Latar Belakang Penulisan Kitab Ma'ājim}

Jika tipologi kitab-kitab Mu'jam yang telah disebutkan di atas dicermati, maka dapat disimpulkan bahwa metodologi penulisan kitab $M u^{\prime}$ jam terbagi menjadi dua, yaitu berdasarkan urutan nama para sahabat (Mu'jam al-ṣahābah) dan berdasarkan urutan para guru-guru pemilik kitab $\mathrm{Mu}^{\prime} \mathrm{jam}$ tersebut (Mu'jam al-shuyūkh). Dengan demikian dapat disimpulkan bahwa latar belakang penulisan kitab Mu'jam yang berdasarkan urutan nama para sahabat ( $M u^{\prime} \mathrm{j}$ jam al-sahăbah) adalah untuk menampilkan riwayat-riwayat para sahabat sekaligus juga untuk mengenalkan biografi mereka kepada para pembacanya.

Kesimpulan semacam ini dapat dilihat ketika misalnya dalam kitab $M u^{\prime}$ jamnya, al-Baghawi menyusunnya sesuai dengan nama-nama para sahabat berdasarkan huruf abjad. Pertama-tama ia menyebutkan biografi sahabat tersebut, terkadang secara ringkas, terkadang juga secara detail. Kemudian ia menyebutkan riwayat-riwayat yang menjelaskan keutamaan para sahabat tersebut, terkadang tanpa sanad dan terkadang pula menggunakan sanad. Selanjutnya ia menuliskan hadis-hadis yang diriwayatkan oleh sahabat tersebut. ${ }^{71}$

Hal yang sama juga diungkapkan oleh al-Thabrāni dalam menyusun al-Mu'jam alKabïr. Ketika kita meneliti kitab al-Mu'jam al-Kabïr karya al-Ṭabranī, maka kita akan mendapati bahwa pokok pembicaraan dari kitab tersebut adalah mengetahui para sahabat dengan menyebutkan ihwal dan keutamaan mereka, lalu menyebutkan riwayatriwayat mereka, baik sebagian maupun keseluruhannya yang disusun berdasarkan urutan abjad. Ia pun memulai susunan para sahabat itu dengan diawali nama-nama sepuluh para sahabat yang dijamin masuk surga oleh Nabi Saw. Dalam muqaddimahnya al-Ṭabrāni berkata:

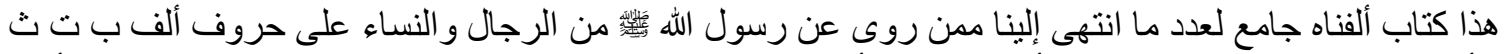

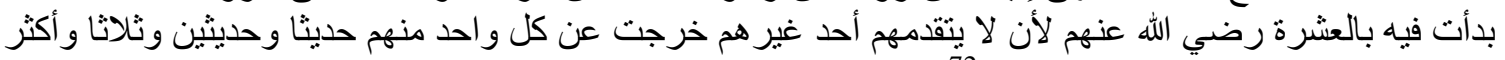

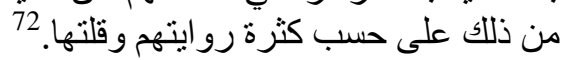

"Kitab ini aku susun dalam rangka mengumpulkan riwayat-riwayat yang telah sampai kepada kami dari orang-orang yang meriwayatkannya dari Rasulullah Saw., baik dari kalangan sahabat laki-laki maupun perempuan sesuai dengan huruf alif, ba, ta, tha. Aku memulainya dengan menyebutkan sepuluh sahabat yang dijamin surga, karena sesungguhnya tidak ada orang lain yang mendahului mereka. Aku mengeluarkan satu, dua, tiga hadis atau lebih dari tiap-tiap mereka sesuai banyak dan sedikitnya riwayat mereka."

\footnotetext{
${ }^{70}$ Sayyid 'Abd al-Māid al-Ghawrī, Mawsū'ah 'Ulūm al-Hadith wa Funūnih, 356.

${ }^{71}$ Muhammad al-Amīn bin Muḥammad al-Jankī, Muqaddimah Mu‘jam al-Sahābah (Kuwait: Dār al-Bayān, 2000), h. 43.

${ }^{72}$ Sulaymān bin Aḥmad bin Ayyūb bin Muṭī al-Lukhamī al-Shāmī al-Ṭabrānī, al-Mu'jam al-Kabīr, vol. 1 (t.t.: t.p., t.th.), h. 1.
} 
Sedangkan latar belakang penulisan kitab $M u$ 'jam yang berdasarkan urutan nama para guru pemilik Mu'jam (Mu'jam al-shuyükh) adalah untuk menghilangkan kesamaran nama-nama guru mereka dan memudahkan dalam meneliti guru-guru mereka yang terdapat dalam kitab mereka. ${ }^{73}$ Selain itu, latar belakang penulisan kitab $M u$ 'jam yang berdasarkan urutan nama para guru pemilik $M u^{\prime} j a m$ ( $M u^{\prime} j a m$ al-shuyūkh) adalah untuk kodifikasi riwayat yang berasal dari guru-guru pemilik $M u^{\prime}$ jam, juga sekaligus sebagai sebuah bentuk mengenang jasa para guru yang telah menyampaikan hadis kepada mereka.

\section{Kualitas Hadis Dalam Kitab Ma'ājim}

Jika melihat definisi dari kitab $M u^{6}$ jam sendiri yaitu tipologi kodifikasi hadis yang didasarkan pada musnad sahabat maupun nama para guru penulis yang disusun berdasarkan huruf abjad, tanpa memberikan syarat-syarat tertentu dalam menampilkan hadis-hadisnya, maka dapat disimpulkan bahwa dalam kitab-kitab $M u$ 'jam secara umum terdapat berbagai kualitas hadis, mulai dari șhịh, hasan, da îf bahkan mawd̄ $\bar{u}^{`}$ (palsu). Kesimpulan ini diperkuat dengan pernyataan al-Dhahabi ketika menilai hadis-hadis dalam al-Mu'jam al-Awsăt yang mengatakan:

عليه, وفيه كو نظيس كتاب الأفر اد للدارقطني بيَّن فيه فضيلته وسعة رو ايته، وكان يقول: هذا الكتاب روحي, فإنه تعب

“Al-Mu'jam al-Awsāt sama dengan kitab al-Afrād yang ditulis oleh al-Dāruqutnī. Di dalamnya ia menjelaskan keutamaan dan keluasan riwayatnya. Al-Ṭabrāni berkata: "Kitab ini adalah ruhku.", karena ia bersusah payah dalam menyusunnya. Di dalamnya terdapat hadis-hadis yang bagus, 'azizz dan munkar."

Namun untuk meneliti kitab $M u$ 'jam mana saja yang di dalamnya terkandung hadis șahịh, hasan, ḍa îf bahkan maw $\bar{u}^{\prime}$ (palsu) tentunya harus dilakukan penelitian yang lebih spesifik terhadap masing-masing kitab $M u^{\prime}$ jam tersebut.

\section{Manfaat atau Peranan Kitab Ma'äjim}

Menurut 'Abd al-'Azīiz bin Șālih al-Luhaydān dalam kitabnya al-Ṭuruq al'Ilmiyyah fi Takhrijj al-Āhädith al-Nabawiyyah, ketika membahas tentang kitab alMu jam al-Kabìr karya al-Ṭabrāni, manfaat atau peranan al-Mu'jam al-Kabïr di ant aranya adalah sebagai berikut:

a. Al-Mu'jam al-Kabïr karya al-Ṭabrāni merupakan salah satu referensi induk hadis-hadis Nabi Saw. yang mempunyai nilai yang sangat penting

b. Al-Mu'jam al-Kabïr karya al-Tabrāni merupakan ensiklopedi hadis yang sangat besar dan banyak memuat hadis-hadis musnad (bersambung dan sampai pada Nabi Saw.)

c. Al-Mu'jam al-Kabïr karya al-Ṭabrāni memuat banyak hadis yang tidak terdapat dalam al-Kutub al-Sittah (Enam Kitab Induk Hadis)

d. Al-Mu'jam al-Kabïr karya al-Ṭabrāni merupakan salah satu referensi utama dalam mengetahui biografi para sahabat, nasab dan keutamaan mereka. ${ }^{75}$

\footnotetext{
${ }^{73}$ Sayyid 'Abd al-Mājid al-Ghawrī, Mawsū'ah 'Ulūm al-Hadìth wa Funūnih, 350. Lihat juga dalam Muqaddimah al-Mu'jam fí Asāmì Suyūkh Abī Bakr al-'Ismā'ili, vol. 1 (Madinah: Maktabah al-'Ulūm wa al-Hikam, 1990), h. 223.

${ }^{74}$ Muhạmmad bin Aḥmad al-Dhahabì, Tadhkirat al-Huffāa, vol. 3 (Beirut: Dār al-Kutub al'Ilmiyyah, 1998), h. 85.

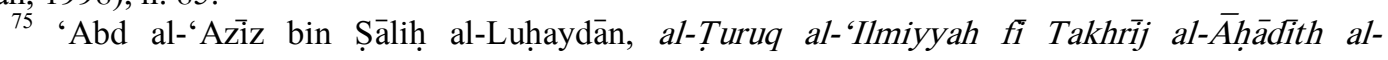
Nabawiyyah, 50.
} 
Manfaat atau peranan kitab al-Mu'jam al-Kabïr karya al-Tabrāni yang telah disebutkan oleh 'Abd al-'Azīz bin Șāliḥ al-Luhaydān di atas menurut penulis juga berlaku bagi kitab-kitab $M u$ 'jam yang lain.

\section{Simpulan}

$M u^{\prime}$ jam adalah tipologi kodifikasi hadis yang didasarkan pada musnad sahabat maupun nama para guru penulis yang disusun berdasarkan huruf abjad. Dalam beberapa sampel di atas terlihat bahwa terkadang kitab $M u$ 'jam juga menampilkan biografi para sahabat terlebih dahulu -seperti al-Mu'jam al-Kabir-, sebelum menampilkan riwayat dari para sahabat tersebut. Dalam beberapa kitab $M u$ jjam ternyata penulis menyebutkan terlebih dahulu nama Muhammad, Ahmad, ataupun nama-nama para sahabat yang mempunyai keutamaan, kemudian diikuti nama-nama yang lainnya berdasarkan huruf abjad secara umum tanpa memperhatikan huruf yang kedua.

Kitab Mu'jam dapat dikelompokkan menjadi dua, Mu'jam al-Shuyūkh (berdasarkan nama-nama para guru) dan $M u$ 'jam al-Sahābah (berdasarkan nama-nama para sahabat). Latar belakang penulisan kitab $M u$ 'jam yang berdasarkan urutan nama para sahabat ( $M u^{\prime} j a m$ al-ṣahābah) adalah untuk menampilkan riwayat-riwayat para sahabat sekaligus juga untuk mengenalkan biografi mereka kepada para pembacanya. Sedangkan latar belakang penulisan kitab $M u$ 'jam yang berdasarkan urutan nama para guru pemilik $M u$ 'jam (Mu'jam al-shuyūkh) adalah untuk menghilangkan kesamaran nama-nama guru mereka dan memudahkan dalam meneliti guru-guru mereka yang terdapat dalam kitab mereka. Selain itu, latar belakang penulisan kitab $M u^{\prime} j a m$ yang berdasarkan urutan nama para guru pemilik Mu'jam (Mu'jam al-shuyūkh) adalah untuk kodifikasi riwayat yang berasal dari guru-guru pemilik $M u^{\prime}$ jam, juga sekaligus sebagai sebuah bentuk upaya mengenang jasa para guru yang telah menyampaikan hadis kepada mereka.

Dalam kitab-kitab $M u$ 'jam secara umum terdapat berbagai kualitas hadis, mulai dari șahịh, hasan, ḍa îf bahkan mawḍ $\bar{u}^{`}$ (palsu). Namun untuk meneliti kitab $M u u^{\prime} j a m$ mana saja yang di dalamnya terkandung hadis șahihh, hasan, da if bahkan mawḍ $\bar{u}^{\circ}$ (palsu) tentunya harus dilakukan penelitian yang lebih spesifik terhadap masing-masing kitab $M u$ 'jam tersebut.

Peranan atau manfaat kitab ma'ājim di antaranya adalah sebagai referensi induk hadis-hadis Nabi Saw, ensiklopedi hadis yang sangat besar dan banyak memuat hadishadis musnad (bersambung dan sampai pada Nabi Saw.), memuat banyak hadis yang tidak terdapat dalam al-Kutub al-Sittah (Enam Kitab Induk Hadis) dan merupakan salah satu referensi utama dalam mengetahui biografi para sahabat, nasab dan keutamaan mereka.

\section{Daftar Pustaka}

Aṣbahānī (al), Abū Nu'aym Aḥmad bin 'Abdillāh. Hilyat al-Awliyā', wa Tabaqāt alAșfiyā', vol. 10. Beirut: Dār al-Kitāb al-'Arabī, $1405 \mathrm{H}$.

'Asqalānì (al), Ibn Hajar. Muqaddimah Fatḥ al-Bāri. Beirut: Dār al-Ma'rifah, 1379 H.

'Ayyārì (al), Badrān Sharh Kitāb Ușūl al-Takhrīj wa Dirāsat al-Asānīd. t.t.: t.p, t.th.

Baghawì (al), Abū al-Qāsim Mu'jam al-Şahābah, vol. 1. Kuwait: Dār al-Bayān, 2000.

Bașrī (al), Aḥmad bin Muḥammad bin Ziyād bin Bishr. Mu'jam Ibn al-A 'rābì. t.t.: t.p., t.th.

Dhahabì (al), Muhammad bin Aḥmad. Siyar A 'ām al-Nubalā', vol. 27. Beirut: Mu'assasah al-Risālah, t.th. 
. Siyar A 'lām al-Nubalā‘, vol. 28. Beirut: Mu'assasah al-Risālah, t.th. . Siyar A 'lām al-Nubalā', vol. 29. Beirut: Mu'assasah al-Risālah, t.th. - Siyar A'lām al-Nubalā', vol. 31. Beirut: Mu'assasah al-Risālah, t.th. . Siyar A 'lām al-Nubalā', vol. 33. Beirut: Mu'assasah al-Risālah, t.th. . Tadhkirat al-Huffaz, vol. 3. Beirut: Dār al-Kutub al-'Ilmiyyah, 1998.

Ghawrī (al), Sayyid 'Abd al-Mājid. Mawsū'ah 'Ulüm al-Hadith wa Funūnih, vol. 3. Damaskus: Dār Ibn Kathïr, 2007.

Hamīd, Sa'd bin 'Abdullāh Ālu. Fatāwā Hadithiyyah. t.t.: t.p., t.th.

'Ilmì (al), Abū Jamìl al-Ḥasan. Ummahàit Kutub al-Hadith wa Manāhij al-Taṣniff 'Inda al-Muhaddithīn. t.t.: Ma'had al-Gharb al-Islāmi, 2005.

'Ismā'îili (al), Abū Bakr. Muqaddimah al-Mu'jam fì Asāmī Suyūkh Abī Bakr al'Ismà iili, vol. 1. Madinah: Maktabah al-'Ulūm wa al-Hikam, 1990.

Janki (al), Muhammad al-Amin bin Muḥammad. Muqaddimah Mu'jam al-Sahābah. Kuwait: Dār al-Bayān, 2000.

Kattānì (al), Muhạmmad bin Ja'far. al-Risālah al-Mustatrafah li Bayān Mashhūr Kutub al-Sunnah al-Mușannafah. Beirut: Dār Bashā'ir al-Islāmiyyah, 1986.

Khațīb (al), Muhammad 'Ajāj. al-Sunnah Qabl al-Tadwin. Beirut: Dar al-Fikr, 1993.

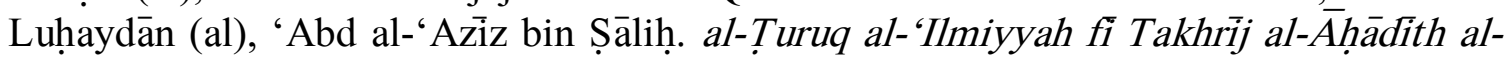
Nabawiyyah. t.t.: t.p., t.th..

Mawșili (al), Abī Ya'lā. al-Mu'jam. Faișal Ābād: Idārah al-'Ulū al-Athariyyah, 1407 H.

Mubārakfūrì (al), 'Ubaidullāh bin Muhammad 'Abd al-Salām. Mir'àt al-Mafătīh Sharh Mishkāt al-Masāäìh, vol. 1. Banaras: Idārah al-Buhüth al-'Ilmiyyah wa alDa'wah wa al-Iftā', 1984.

Qanūjìi (al), Al-Sayyid Șadiq Hasan. al-Hițtah fì Dhikr al-Sị̣ạh al-Sittah. Beirut: Dār al-Kutub al-Ta'Timiyyah, 1985.

Sa'd (al), Abdullāh. Sharh al-Müqiḍah fí 'Ilm al-Muștalah, vol. 1. t.t.: t.p., t.th.

Salāmah, Muhammad Khalaf. Lisān al-Muhaddithīn, vol. 5. t.t.: t.p., t.th.

Ṭabrānī (al), Sulaymān bin Aḥmad bin Ayyūb bin Muṭîr al-Lukhamī al-Shāmī. alMu'jam al-Kabir, vol. 16. t.t.: t.p., t.th. . al-Mu'jam al-Kabir, vol. 2. t.t.: t.p., t.th. . al-Mu'jam al-Kabir, vol. 1. t.t.: t.p., t.th. . al-Mu ‘jam al-Awsät. Kairo: Dār al-Haramayn, $1415 \mathrm{H}$.

. al-Mu'jam al-Saghìr, vol. 1. Beirut: al-Maktab al-Islāmī, 1985.

'Umarì (al), Akram Diyā'. Buhūth fì Tārīkh al-Sunnah al-Musharrafah. Madinah: Maktabah al-'Ulüm wa al-Ḥikam, t.th. 